\title{
Suppression of the soybean cyst nematode, Heterodera glycines, by short-term field cultivation and soil incorporation of mung bean
}

Seiya ChiKAmatsu ${ }^{1}$, Ai TAKedA ${ }^{2}$, Kazuhiro OHtA $^{3}$, Takeo IMURA $^{4}$, Roland N. Perry $^{5}$
and Koki ToyotA

10

${ }^{1}$ Graduate School of Bio-Applications and Systems Engineering, Tokyo University Agriculture and Technology, 2-24-16 Nakacho, Koganei, Tokyo 184-8588, Japan

${ }^{2}$ Chiba Prefectural Agriculture and Forestry Research Center, 808 Daizenno, Midori, Chiba 266-0006, Japan

${ }^{3}$ Kanagawa Agricultural Technology Center Miura Peninsula Regional Office, 3002 Shimomiyada, Hasse-machi, Miura, Kanagawa 238-0111, Japan

${ }^{4}$ Nara Prefecture Agricultural Research and Development Center, 130-1 Ikenouchi, Sakurai, Nara 633-0046, Japan ${ }^{5}$ University of Hertfordshire, Hatfield, Hertfordshire AL10 9AB, UK

Received: 13 May 2020; revised: 26 June 2020 Accepted for publication: 26 June 2020

* Corresponding author, e-mail: kokit@cc.tuat.ac.jp 
Summary - Our previous study using pots reported that short-term growth of mung bean (Vigna radiata) may be useful to decrease the density of soybean cyst nematode (SCN), Heterodera glycines, in soil. The objective of this study was to determine whether short-term growth of mung bean and its incorporation by ploughing decreased the SCN density in infested fields. Firstly, we did pot experiments to evaluate the optimum temperature and moisture for hatching in soil. SCN hatching was stimulated at $25^{\circ} \mathrm{C}$ and $30^{\circ} \mathrm{C}$ and not at $20^{\circ} \mathrm{C}$; however, it was stimulated at alternating temperature conditions between $20^{\circ} \mathrm{C}$ and $25^{\circ} \mathrm{C}$. Soil moisture levels with $\mathrm{pF} 2.76$ or less were required to stimulate $\mathrm{SCN}$ hatch in soil. Field experiments were done in Saitama, Kanagawa and Nara Prefectures, Japan. SCN density was reduced by nearly half even in control plots, in which mung bean was not cultivated and ploughed, in Saitama and Nara Prefectures. However, SCN density was reduced by nearly $80 \%$ or more in the three prefectures, except for one plot in Kanagawa, and the soil temperature and moisture conditions were kept around $20^{\circ} \mathrm{C}$ to $30^{\circ} \mathrm{C}$ and at $<\mathrm{pF} 2.8$. Increase in yield of green soybean by SCN control was estimated $350 \mathrm{~kg}(1000 \mathrm{~m})^{-2}$. Overall, the present study revealed that short-term field cultivation of mung bean and ploughing was a profitable method to decrease SCN density in infested fields and thereby to increase yield of green soybean.

Keywords - field experiment, green manure, Japan, real-time PCR, soil moisture, soil temperature, Vigna radiata. 
Soybean (Glycine max (L.) Merr) is a major and important crop around the world. However, yield losses are caused by many pests, e.g., soil fungi Rhizoctonia solani Kuhn (Ajayi-Oyetunde \& Bradley, 2018) and Peronospora manshurica Syd (Da Silva et al., 2016), insects such as soybean aphid (Aphis glycines Matsumura) (Tilmon et al., 2011) and bean leaf beetle (Cerotoma trifurcate Forster) (Smelser \& Pedigo, 1992), and 60 soybean cyst nematodes ( $\mathrm{SCN}$ ), Heterodera glycines Ichinohe. In the USA, yield losses due to SCN were 1.9 million tonnes in the major production regions in 2005 , and were greater than losses caused by any other disease (Wrather \& Koenning, 2006). In Japan, SCN mainly causes yield losses of soybean and green soybean, which is immature soybean. The damage has spread not only in Hokkaido (Aiba, 2001), which is the main prefecture for soybean production, but also in urban areas such as Chiba and Saitama (Chikamatsu et al., 2017), which are the main prefectures for green soybean production.

To control nematodes including SCN, there are several biological and non-biological methods. As non-biological control, nematicides are effective but economic and environmental issues have increasingly limited their use (Rich et al., 2004). Of the biological control methods, resistant soybean cultivars have reduced the density of SCN and increased soybean yields (Chen, 2007), and crop rotation with non-host crops reduced the density of SCN (Sasser \& Uzzell, 1991). However, in urban areas in Japan, it is difficult to adopt crop rotation and to use nematicides, especially fumigant types, because the land prices are high and fields and residential zones are close. Thus, we need to develop environmentally friendly management strategies for SCN that have limited negative environmental impact (Grabau \& Chen, 2014).

The invasive second-stage juveniles (J2) of $H$. glycines hatch more in response to stimulation by exudates from host roots. If hatch can be caused in the absence of hosts the $\mathrm{J} 2$ will die and the population will decrease, providing a good control strategy. Many

80 studies have reported on hatch and density reduction of SCN. For example, glycinoeclepin A, which was extracted and identified from dried roots of kidney beans (Phaseolus vulgaris L.) (Masamune et al., 1982), promotes hatch of SCN and may be effective in reducing the density of SCN, but is expensive to synthesise and is not feasible for field application (Shiina et al., 2010). Sunn hemp (Crotalaria juncea L.) and red clover (Trifolium pratense L.) are known to stimulate hatch and thereby to reduce SCN populations (Kushida et al., 2002, 2003). However, they often do not match the crop 
system, particularly in urban areas, because it takes several months to cultivate these green manures. Recently, attention on SCN control has increased. Extracts from camellia (Camellia oleifera Abel) and Paeonia sp. inhibited hatch of SCN (Wen et al., 2019). The density of SCN in soil was decreased by growing winter camelina (Camelina sativa $\mathrm{L}$. Cranz) for 35 days in a growth chamber (Acharya et al., 2019), or growing cereal rye (Secale cereale L.) and rapeseed (Brassica napus L.) for several months in fields and their subsequent incorporation into the soil (Wen et al., 2017).

We previously reported that incorporation of bean sprout residue or its water extract to soil stimulated hatch of $\mathrm{J} 2$ and decreased SCN density (Toyota et al., 2013; Ito et al., 2015). However, it is difficult to apply the residue of bean sprout (Vigna radiata (L.) Wilczek) to fields because the residue contains more than $90 \%$ water and the application rate $\left(5,000 \mathrm{~kg}(1000 \mathrm{~m})^{-2}\right.$ is too high. Therefore, we developed an alternative method using mung bean, which is the raw material of bean sprouts. In this method, mung bean

100 was sown in soil, grown for 2 to 4 weeks, and then incorporated into the soil. The benefit of mung bean growth and its incorporation requires only a short-term growth period, while other green manures require more than 1 month (Wen et al., 2017; Acharya et al., 2019; Kushida et al., 2002, 2003). By this process, hatch of J2 was stimulated and SCN density was decreased (Chikamatsu et al., 2017). All these experiments were done in pots.

105 Thus, the objective of this study was to evaluate the effects of growing and incorporating mung bean on SCN density in SCN infested fields.

\section{Materials and methods}

110 SOILS

Four soils naturally infested with SCN were collected from farmlands and their basic data are shown in Table 1. Soil moisture release curves were constructed using a Multi-Fold pF Meter (Daiki Rika Kogyo Co., Ltd). For S and K soils, soil passed through

115 a $5 \mathrm{~mm}$ sieve was packed tightly in 100-ml cores in three and seven replicates, respectively. For N soil, a 100 cc core was collected from a field (Supplementary Fig. $\mathrm{S} 1)$.

To use a moisture sensor (5TM, Decagon Device) in fields, we evaluated the 
relationship between values of $5 \mathrm{TM}\left(\mathrm{m}^{3} \mathrm{~m}^{-3}\right)$ and the actual soil moisture contents, that were measured by oven-drying. Soil ( $800 \mathrm{~g})$ was mixed with 30 to $120 \mathrm{ml}$ of water and tightly packed into a pot with $100 \mathrm{~cm}^{2}$ surface area and the moisture content was measured with 5TM operated by a measuring instrument (ProCheck, Decagon Device). Then, $20 \mathrm{~g}$ of the soil was collected and dried at $105^{\circ} \mathrm{C}$ overnight to measure the absolute water content. Water was re-added to the soil remaining in the pot. The soil was mixed

125 well and tightly packed in the pot and the moisture content was measured with 5TM. This process was repeated several times for each soil. The relationship between values of 5TM and soil moisture content is shown in Supplementary Figure S2.

In the following pots and field experiments, soil moisture content was measured with $5 \mathrm{TM}$ and its $\mathrm{pF}$ value was calculated according to the calibration curves of

130 Supplementary Figures S1 and S2.

\section{EFFECT OF TEMPERATURE ON SCN HATCHING}

The optimal temperature range for hatching was determined. Firstly, to prepare hatching stimulus, 12 to 15 seeds (about 8 to $9 \mathrm{~g}$ ) of mung bean seeds ('Green Mappe', Nakahara Seed Co.) were sown in a plastic cup with a $9 \mathrm{~cm}$ diameter containing $\mathrm{C}$ soil. A total of nine cups were grown in a growth chamber at $25^{\circ} \mathrm{C}$ with $16 \mathrm{~h}: 8 \mathrm{~h}$ light : dark cycle for 1 week. All the mung bean plants including the roots were collected from the pots, cut into $3 \mathrm{~cm}$ pieces with scissors, and shaken in $500 \mathrm{ml}$ distilled water at $80 \mathrm{rpm}$ for

$1406 \mathrm{~h}$. The resulting solution was filter-sterilised $(0.2 \mu \mathrm{m}$ pore size $)$ and stored at $4{ }^{\circ} \mathrm{C}$ until use.

Air-dried C soil (100 g) was put in four replicates in a plastic cup with a $9 \mathrm{~cm}$ diameter and $30 \mathrm{ml}$ of the mung bean solution prepared above was added. The pots were incubated at $20^{\circ} \mathrm{C}, 25^{\circ} \mathrm{C}$, and $30^{\circ} \mathrm{C}$ and $20 \mathrm{~g}$ soil was taken in duplicate after $0,2,4,7$ and 11 days.

145 To measure the number of hatched SCN J2, nematodes were extracted with the Baermann funnel extraction method ( 3 days incubation at $25^{\circ} \mathrm{C}$ ).

Next, to simulate actual temperature fluctuations in field, we evaluated the effect of temperature change between $20^{\circ} \mathrm{C}$ and $25^{\circ} \mathrm{C}$. Pots containing $100 \mathrm{~g}$ of air-dried $\mathrm{C}$ soil were incubated in triplicate: $i$ ) at $20^{\circ} \mathrm{C}$ for $24 \mathrm{~h}$; ii) at $20^{\circ} \mathrm{C}$ for $12 \mathrm{~h}$ and at $25^{\circ} \mathrm{C}$ for $12 \mathrm{~h}$; 150 and $\mathrm{iii}$ ) at $25^{\circ} \mathrm{C}$ for $24 \mathrm{~h}$. After $1,3,6,10$ and 14 days, $20 \mathrm{~g}$ of soil was taken in duplicate 
from the pots for the Baermann funnel extraction to observe the number of hatched $\mathrm{J} 2$ using a stereoscopic microscope. In both experiments, pots were covered with a plastic bag to avoid water evaporation during the incubation period.

S soil (36 kg dry soil basis) was put into a container with a volume of 351 . Half of the container was sown with mung bean (11 seeds, corresponding to $18 \mathrm{~g} \mathrm{seed}^{-2}$ ) and the other half was not sown. The mung bean was grown for 18 days in a glasshouse. The soil moisture was $\mathrm{pF} 1.9$ at sowing and decreased to $\mathrm{pF} 3.0$ after 18 days. Soil was separately collected from the non-mung bean part (control) and mung bean part (MB) and mixed well to homogenise the density of SCN. Then, the mixed soil was divided into 18 bags (1 $\mathrm{kg}$ fresh soil (= $740 \mathrm{~g}$ of dry soil each bag)). All the mung bean plants, including roots, were gently removed from the container and cut into $1 \mathrm{~cm}$ pieces with scissors. Since the 165 plant sample weighed $11.2 \mathrm{~g}, 0.62 \mathrm{~g}$ (11.2 g divided by $18 \mathrm{bags})$ was added to each bag of MB soil. The control and MB soils were mixed well after adding different amounts of water to adjust their moisture content to between $\mathrm{pF} 2.0$ and $\mathrm{pF}$ 3.0. Six water levels were prepared in three replicates. Each soil in plastic bags was put into a pot with $100 \mathrm{~cm}^{2}$ surface area and then the soil moisture levels were measured with 5TM. The pots were

170 wrapped to avoid moisture evaporation and put on a heating mat. At 0 and 4 days, the soil was mixed well and then $20 \mathrm{~g}$ was taken in duplicate for the Baermann funnel extraction method ( 2 to 3 days incubation at room temperature) to determine the number of hatched $\mathrm{J} 2$ of SCN using a stereoscopic microscope. The average soil temperature during 4 days was $23.6^{\circ} \mathrm{C}$.

175

FIELD EXPERIMENTS

\section{Saitama Prefecture}

180 In a field covered with plastic film $(5 \mathrm{~m} \times 50 \mathrm{~m})$ in Saitama Prefecture, we conducted the following experiment consisting of five treatments: 1, control (no mung bean and no irrigation); 2, MB9 (sowing rate of mung bean was $9 \mathrm{~g} \mathrm{~m}^{-2}$, an amount recommended by 
Chikamatsu et al. (2017), and irrigation was done only at sowing); 3, MB9i (sowing rate, $9 \mathrm{~g} \mathrm{~m}^{-2}$ and irrigation was done both at sowing and ploughing); 4, MB18i (sowing rate, 18 $\mathrm{g} \mathrm{m}^{-2}$ and two times irrigation); and 5, MB27i (sowing rate, $27 \mathrm{~g} \mathrm{~m}^{-2}$ and two times irrigation). The treatment size of control and MB9 were each $25 \mathrm{~m}^{2}(5 \mathrm{~m} \times 5 \mathrm{~m})$, and MB9i, MB18i and MB27i were each $65 \mathrm{~m}^{2}(13 \mathrm{~m} \times 5 \mathrm{~m})$. Nine plots $\left(0.36 \mathrm{~m}^{2}, 0.6 \mathrm{~m} \times 0.6\right.$ m) were set up at even intervals in each treatment. On 6 July 2018 (before sowing), tillage was done with a tractor and then soil in each plot was manually thoroughly mixed with a

190 shovel. Five soil cores $(0-20 \mathrm{~cm})$ were sampled from each plot with a root auger and a composite sample was made for each plot. Mung bean seeds were sown and the soil surface was raked to stimulate germination. Watering was done using irrigation tubes at $20 \mathrm{~m}^{-2}$ to the whole field except for the control treatment. On 7, 8 and 9 July 2018, watering was done at a rate of $201 \mathrm{~m}^{-2}$ to the whole field except for the control treatment,

195 and in 10 July 2018, watering was done at $101 \mathrm{~m}^{-2}$ to the whole field except for the control treatment, in order to stimulate mung bean growth. On 26 July 2018, plant densities of mung bean were measured in each plot and then the mung bean plants were ploughed with a tractor. To stimulate $\mathrm{SCN}$ hatch, treatments MB9i, MB18i, and MB27i were irrigated at a rate of $40 \mathrm{l} \mathrm{m}^{-2}$. Summary of the managements is shown in Table 2. In

200 August 25, 2018, soil samples were taken to measure the SCN density using real-time PCR, as described below. Sensors (5TM) were inserted in duplicate to a depth of $10 \mathrm{~cm}$ to $15 \mathrm{~cm}$ in MB9 and MB9i and soil temperature and moisture were measured at intervals of $1 \mathrm{~h}$ with a data logger (Em50, Decagon).

Four naturally infested fields were used for the field experiment. Three plots $\left(1 \mathrm{~m}^{2}, 1 \mathrm{~m}\right.$ $\times 1 \mathrm{~m}$ ) were set up in each field (Table 2). Before sowing mung bean seeds, the soil was collected from five points in each plot and a composite sample made for each plot. Two to 210 five days later, seeds were sown at $9 \mathrm{~g} \mathrm{~m}^{-2}$ in each field. After growing for 25 to 44 days, mung bean was ploughed into each field with a tractor and soil was collected from each plot. Two weeks after ploughing, soil was again collected from each plot. The management schedule is shown in Supplementary Table S1. Sensors (5TM) were inserted 
to a depth of $10 \mathrm{~cm}$ to $15 \mathrm{~cm}$ in each field and soil temperature and moisture were measured at intervals of $1 \mathrm{~h}$ with a data logger (Em50, Decagon).

\section{Nara Prefecture}

In Saitama and Kanagawa Prefectures, green soybean is generally cultivated from

220 March to July. Thus, mung bean was grown in July to September after harvest of green soybean in the prefectures. The maximum temperature for $\mathrm{SCN}$ hatch is $25^{\circ} \mathrm{C}$ (Ito et al., 2015) and therefore July to September is a suitable period for SCN hatch. By contrast, green soybean is generally cultivated from July to October in Nara Prefecture. An available period for mung bean cultivation is May, when soil temperature is generally lower than $25^{\circ} \mathrm{C}$. To increase the soil temperature, mulching was used in Nara Prefecture. A naturally infested field was divided into two parts; control (no mung bean) and mung bean part $(\mathrm{MB})$. In each part, three plots $\left(1 \mathrm{~m}^{2}, 1 \mathrm{~m} \times 1 \mathrm{~m}\right)$ were set up. In the mung bean part, mung bean seeds were sown at $9 \mathrm{~g} \mathrm{~m}^{-2}$ on 22 May. On 4 June 2018, mung bean plants were ploughed by a tractor. After ploughing, the mung bean part was mulched with black polyethylene films (Table 2). Soil was collected from five points in each plot on sowing, 5 days before ploughing, the day after ploughing, and three weeks after ploughing. Sensors (5TM) were inserted to a depth of $10 \mathrm{~cm}$ to $15 \mathrm{~cm}$ in a control plot and in a mung bean plot and soil temperature and moisture were recorded at intervals of $1 \mathrm{~h}$ with a data logger (Em50, Decagon).

235

\section{QUANTIFICATION OF THE DENSITY OF HETERODERA GLYCINES}

The densities of SCN in soils were estimated using the real-time PCR method (Toyota et al., 2013) with some modifications. Composite samples from five points in

240 each plot were passed through a 2-mm sieve to make homogeneous samples and oven-dried at $60^{\circ} \mathrm{C}$ for 1 to 2 days. Ten $\mathrm{g}$ of the dried soils were taken in three replicates from each plot and pulverised into powder for 2 min at $45 \mathrm{~m} \mathrm{~s}^{-1}$ in a ball-mill (Fast Prep; MP Biomedicals). The total of $30 \mathrm{~g}$ was combined for each plot and then used for DNA extraction. DNA was extracted in duplicate from $5 \mathrm{~g}$ using a modified method reported by

245 Cheng et al. (2018). Briefly, DNA was extracted from the ball-milled soils with 
phosphate buffer and purified with a commercially available column. Purified DNA extracts were used as templates in real-time PCR after ten-fold dilution. Real-time PCR was performed using a Step One Real-Time PCR System (Life Technologies Japan) in a final volume of $10 \mu 1$ containing $5 \mu 1$ of a Fast SYBR Green Master Mix (Life

250 Technologies Japan), $5 \mathrm{mM}$ of each primer (SCNnew-f(ITS1, 5'- CTG CAC ATG TGA AAG CCT GTG TA-3') and SCNnew-r (ITS1, 5'-GAG CGT GCA TCC CAC ATT G-3')) (Shirai \& Toyota, 2019) and $2 \mu$ of template DNA under the manufacturer's recommended conditions $\left(95^{\circ} \mathrm{C}\right.$ for $10 \mathrm{~s},\left(95^{\circ} \mathrm{C}\right.$ for $5 \mathrm{~s}$ and $60^{\circ} \mathrm{C}$ for $\left.20 \mathrm{~s}\right) \times 40$ cycles $) . \mathrm{Ct}$ values (y) obtained with the primer set were converted to the densities ( $\mathrm{x}: \log _{10}$ eggs equivalent $\left.(20 \mathrm{~g} \text { dried soil })^{-1}\right)$ of SCN using the calibration curve $(y=-2.82 \mathrm{x}+34.5)$ (Shirai \& Toyota, 2019).

\section{Statistical analysis}

260 Significant differences among mean values were analysed by Fisher's test at 5\% with one-way ANOVA using Excel Statistics (Social Survey Research Information) software. Homogeneity of variances was testing using Levene's test and normal distribution of residuals was assessed using Statcel $3^{\text {rd }}$ ed (OMS publication). Suitable transformations (log: Fig. 1A and Supplementary Figs S3, S4), square root: Fig. 1B) were used when data 265 did not meet assumptions.

\section{Results}

\section{EFFECT OF TEMPERATURE ON SCN HATCHING}

There was no significant difference $(P<0.05)$ in the $20^{\circ} \mathrm{C}$ treatment during the incubation period, indicating no hatch at $20^{\circ} \mathrm{C}$ (Fig. 1A). On the other hand, the number of SCN J2 increased in the $25^{\circ} \mathrm{C}$ and $30^{\circ} \mathrm{C}$ treatments and reached a maximum on day 4 , indicating that $\mathrm{SCN}$ hatched both at $25^{\circ} \mathrm{C}$ and $30^{\circ} \mathrm{C}$. The increasing numbers of SCN J2 from 0 to 4 days were higher at $25^{\circ} \mathrm{C}\left(45 \mathrm{~J} 2(20 \mathrm{~g} \text { soil })^{-1}\right)$ than at $30^{\circ} \mathrm{C}\left(33 \mathrm{~J} 2(20 \mathrm{~g} \mathrm{soil})^{-1}\right)$, although there was no significant $(P=0.56)$ difference. 
Under fluctuating temperature conditions between $20^{\circ} \mathrm{C}$ and $25^{\circ} \mathrm{C}$, the maximum number of SCN J2 that hatched was similar to the numbers at constant $25^{\circ} \mathrm{C}$, although the period to reach the maximum number was longer (Fig. 1B), being 3 days at $25^{\circ} \mathrm{C}$ and 10 days at fluctuating temperatures.

\section{EFFECT OF SOIL MOISTURE ON SCN HATCHING}

There was no difference in the number of $\mathrm{J} 2$ that hatched in control among soils with different $\mathrm{pF}$ values. By contrast, the number of $\mathrm{J} 2$ in $\mathrm{MB}$ increased with decrease in $\mathrm{pF}$, i.e., with higher moisture content. There was no significant difference $(P=0.21)$ in soil with $>$ pF 2.9 between control and MB. However, the number of $\mathrm{J} 2$ was significantly higher $(P<0.05)$ in MB than in control, when soil moisture was $<$ pF 2.76 (Fig. 2).

\section{FIELD EXPERIMENTS}

\section{Saitama Prefecture}

When mung bean was grown for 20 days and ploughed, the above-ground biomass was $587 \mathrm{~g} \mathrm{~m}^{-2}$ for MB9, $736 \mathrm{~g} \mathrm{~m}^{-2}$ for MB9i, 1,310 $\mathrm{g} \mathrm{m}^{-2}$ for MB18i and 1,706 $\mathrm{g} \mathrm{m}^{-2}$ for MB27i at fresh weight (Supplementary Fig. S3). It was significantly higher $(P<0.05)$ in MB18i and MB27i than in MB9 and MB9i, and there was no significant difference between MB18i and MB27i $(P=0.07)$.

The density of SCN decreased by nearly $50 \%$ in the control between before sowing and 30 days after mung bean ploughing (Fig. 3). By contrast, it decreased by nearly $80 \%$ in all MB treatments. There was significant difference $(P<0.05)$ between control and all MB treatments.

Immediately after sowing mung beans, MB9, MB9i, MB18i and MB27i were irrigated between 6 to 10 July to enhance mung bean germination. During this period, the moisture level in MB9 ranged between $\mathrm{pF} 2.2$ and $\mathrm{pF} 2.4$, and in MB9i between $\mathrm{pF} 2.3$ and $\mathrm{pF} 2.8$. The soil moisture 2 days after ploughing ranged from $\mathrm{pF} 2.0$ to $\mathrm{pF} 2.4$ in MB9i for irrigation and gradually deceased (Fig. 4). On the other hand, the soil moisture in MB9 increased to a similar level in MB9i 2 days after ploughing. The average soil temperature 
for 30 days after ploughing was $30.5^{\circ} \mathrm{C}$ for MB9 and $28.5^{\circ} \mathrm{C}$ for MB9i (Supplementary

310 Fig. S4).

\section{Kanagawa prefecture}

The ratio of SCN density 2 weeks after ploughing to that before sowing was less than $31520 \%$ in two plots in fields 1 and 2 and in all plots in field 4 (Fig. 5). In field 3, SCN density decreased in two plots; however, it increased from 171 to 436 eggs equivalent 20 $\mathrm{g}^{-1}$ soil in one plot. SCN density was significantly lower $(P<0.05) 2$ weeks after ploughing than before sowing in fields 1,2 , and 4 , except for field $3(P<0.05)$.

The average soil moisture and temperature for 14 days after mung bean ploughing 320 were $<\mathrm{pF} 2.8$ and nearly $25^{\circ} \mathrm{C}$ (Supplementary Table S2).

\section{Nara Prefecture}

The initial density of SCN, 5 days before ploughing, was similar between the control and MB. The ratio of SCN density 22 days after ploughing to that at five days before ploughing was $42 \%$ in control, while it was only $5 \%$ in $\mathrm{MB}$, and these values were significantly different $(P<0.05)$ (Fig. 6). From two days after ploughing, soil moisture increased in $\mathrm{MB}$ and consistently remained at $<\mathrm{pF} 2.8$, while in the control it sometimes dried to near pF 2.8 (Supplementary Fig. S5). Daily changes in soil temperature after ploughing were smaller in MB than in the control and the soil temperatures remained higher in MB than in the control (Supplementary Fig. S6). The average soil moisture and temperature were higher in $\mathrm{MB}\left(23.1^{\circ} \mathrm{C}\right.$ and $\left.\mathrm{pF} 1.8\right)$ than in control $\left(21.3^{\circ} \mathrm{C}\right.$ and $\left.\mathrm{pF} 2.2\right)$.

\section{Discussion}

We previously reported that short-term growth and incorporation of mung bean in pots stimulated SCN hatching and then decreased SCN density (Chikamatsu et al., 2017). This study was conducted to show whether short-term cultivation of mung bean and its ploughing in fields decreased the population density of SCN in the soil. Two climatic factors are mainly involved in the efficacy to decrease SCN density: temperature and 
moisture (Chikamatsu et al., 2017). In previous studies, different optimal temperatures were reported for SCN hatching. It was between $25^{\circ} \mathrm{C}$ and $30^{\circ} \mathrm{C}$ in studies by Okada (1971, 1977), whilst Ito et al. (2015) reported an optimum of $25^{\circ} \mathrm{C}$, with only a few SCN hatching at $30^{\circ} \mathrm{C}$. When mung bean cultivation is implemented in fields, it is necessary to consider a cropping period based on temperature. Therefore, the optimum temperature was again evaluated in this study. The results showed that hatching was stimulated at $25^{\circ} \mathrm{C}$ and $30^{\circ} \mathrm{C}$, but not at $20^{\circ} \mathrm{C}$. However, hatching was stimulated by alternating temperature conditions at $20^{\circ} \mathrm{C}$ and $25^{\circ} \mathrm{C}$, although hatching was delayed compared with that at a constant temperature of $25^{\circ} \mathrm{C}$. These results suggest that periods of temperatures of $25^{\circ} \mathrm{C}$ and $30^{\circ} \mathrm{C}$ are most favourable for stimulating SCN hatch, but that hatch stimulation may occur even in much cooler temperature conditions, e.g., night time temperatures of $20^{\circ} \mathrm{C}$, with day time temperatures reaching $25^{\circ} \mathrm{C}$.

Chikamatsu et al. (2017) showed the importance for hatch stimulation of ploughing, rather than continuous growth of mung beans, and the soil moisture content at ploughing. 355 Wallace (1954) showed that SCN J2 rarely hatch in soil with a moisture level of pF 3.0. However, it was still not known how soil moisture level affects hatching after mung bean incorporation. The present study suggested that a soil moisture level with least $\mathrm{pF} 2.76$ or less was required to stimulate $\mathrm{SCN}$ hatch.

In the present study, pot experiments revealed the optimal soil temperature and 360 moisture conditions, so we tested the biocontrol method for SCN consisting of short-term mung bean cultivation and its subsequent ploughing of mung bean in SCN infested fields in Saitama, Kanagawa, and Nara Prefectures. The density of SCN decreased even in the control soil not sown with mung bean in both Saitama and Nara Prefectures. According to Perry (2002), SCN hatch moderately in water when soil temperature conditions are

365 suitable for hatching. Thus, it was considered that some SCN hatched without the effect of mung bean and then, in the absence of host plants, starved to death. However, the density of SCN in soil sown with mung bean decreased much more than that in the control soil. The density of SCN decreased even in MB9, which was not irrigated after mung bean ploughing and was over $\mathrm{pF} 3.0$ at ploughing, indicating that few $\mathrm{J} 2$ hatch in dry 370 moisture conditions of $\mathrm{pF} 2.8$. There was heavy rainfall of $48 \mathrm{~mm} 2$ days after ploughing. The experiment using field soil was in a glasshouse covered with plastic film and there was no direct rain on the soil; however, soil moisture of MB9 was increased by water 
supply through underground water and reached a similar level 6 days after ploughing to that in MB9i which was irrigated after ploughing. Thus, it was considered that the increased soil moisture in MB9 may stimulate SCN hatch and thereby decreased the SCN density.

In Kanagawa Prefecture, the density of SCN was decreased by more than $80 \%$ by growing mung bean and ploughing, except for Field 3. In Kanagawa, no control plot was set up and it was impossible to separate mung bean effect from natural phenomena.

380 However, the soil moisture and temperature for 14 days after mung bean ploughing showed values closer to the optimal conditions ( $\mathrm{pF} 2.0$ to 2.6, soil temperature 24 to $25^{\circ} \mathrm{C}$ ), suggesting that mung bean cultivation and ploughing may stimulate SCN hatch and thereby decrease SCN density. The reason why SCN density increased in one plot in Field 3 was unknown.

In Nara prefecture, the density of SCN decreased to almost zero in mung bean plots. The density reduction was greater than that in the Saitama and Kanagawa Prefectures. This was considered to be due to the black mulch covering the plot in which mung bean was grown and ploughed, which maintained the high water content $(\mathrm{pF} 2.1$ or less, from 1 to 22 days after ploughing) and appropriate hatching temperatures $\left(23.1^{\circ} \mathrm{C}\right.$, for 22 days

390 after ploughing). In Saitama Prefecture, soil moisture exceeded pF 2.8 for nearly a half of the 30 days after mung bean ploughing, indicating less favourable conditions for SCN hatch. Thus, the remaining population of SCN was higher in Saitama Prefecture than in Nara Prefecture.

In Saitama Prefecture, the effect of sowing rate of mung bean was evaluated, ranging 395 from $9 \mathrm{~g} \mathrm{~m}^{-2}$ to $27 \mathrm{~g} \mathrm{~m}^{-2}$ and there was no apparent change in the decreasing effect on SCN density. This result suggests that a sowing rate of $9 \mathrm{~g} \mathrm{~m}^{-2}$ was appropriate. Profitability in 1,000 $\mathrm{m}^{-2}$ was estimated based on the following: an expected increase in yield of green soybean due to a $80 \%$ reduction of SCN density was $350 \mathrm{~kg}$, based on Ito et al. (2017) and the following assumption that the initial density of 2,000 eggs equivalent $400(20 \mathrm{~g} \text { soil })^{-1}$, and yield of green soybean of $1,470 \mathrm{~kg}(1,000 \mathrm{~m})^{-2}$, green soybean price in Saitama Prefecture of 500 yen $\mathrm{kg}^{-1}$, fuel costs for tillage $(\times 2)(3,642$ yen), labour cost: 1000 yen $\mathrm{h}^{-1}$, seeds $(7,200$ yen for $9 \mathrm{~kg})$, water irrigation and associated tube cost $(9,920$ yen). From these data, the yield increase by reducing SCN density was determined to be 
more than the necessary costs, and the profit was calculated to be 153,000 yen $(1,400$

405 US\$) $(1,000 \mathrm{~m})^{-2}$.

\section{Conclusions}

The present study found in pot experiments that hatching of $H$. glycines was

410 stimulated under temperature conditions of $20^{\circ} \mathrm{C}$ to $30^{\circ} \mathrm{C}$ and moisture conditions of < $\mathrm{pF}$ 2.8. We demonstrated in field experiments that short-term field cultivation of mung bean and ploughing was a profitable method to decrease SCN density in infested fields and thereby increase yield of green soybean.

\section{Acknowledgements}

We would like to thank Mr Minegishi, Y., Terashita, Y., and Yoshioka, R., Saitama Prefecture; Kato, N., Kanagawa Prefecture; Takenaka, I., Nara Prefecture, and the farmers who kindly provided us with the soil samples. Additionally, we also thank Mae,

420 H. and Oda, S. who helped us in soil analyses, and Fujita, T., Shirai, S., Makuta, K. and Yang Y.Y. who helped us in the soil sampling and measurement of mung bean weights. This research was partly funding by a grant from the Project of the NARO Bio-oriented Technology Research Advancement Institution (the special scheme project on regional development strategy).

425

\section{References}

Acharya, K., Yan, G. \& Berti, M. (2019). Can winter camelina, crambe, and brown mustard reduce soybean cyst nematode populations? Industrial Crops \& Products 140, UNSP 111637. DOI: 10.1016/j.indcrop.2019.111637

Aiba, S. (2001). Ecology and prevention of soybean cyst nematode. Plant Protection 55, 229-232. 
Ajayi-Oyetunde, O.O. \& Bradley, C.A. (2018). Rhizoctonia solani: taxonomy, population biology and management of rhizoctonia seedling disease of soybean. Plant Pathology 67, 3-17. DOI: 10.1111/ppa.12733

Chen, S. (2007). Tillage and crop sequence effects on Heterodera glycines and soybean yields. Agronomy Journal 99, 797-807. DOI: 10.2134/agronj2006.0150

Cheng, Z., Shirai, S., Toyota, K. \& Ritz, K. (2018). Case study on a modified method to quantify the density of some soil-borne plant-parasitic nematodes in a simpler and less expensive way. Nematological Research 48, 11-17. DOI: 10.3725/jjn.48.11

Chikamatsu, S., Wang, X., Ito, D., Yamada, E. \& Toyota, K. (2017). Effect of short-term growth of mung bean and its soil incorporation on the density of the soybean cyst nematode, Heterodera glycines, in pot experiments. Nematology 19, 1147-1155. DOI: $10.1163 / 15685411-00003114$

445 Da Silva, O.C., Santos, H.A.A., Pria, D.M. \& Demio, L.L.M. (2016). Damage to soybean caused by downy mildew. Ciencia Rural 46, 389-392.

Grabau, Z.J. \& Chen, S. (2014). Efficacy of organic soil amendments for management of Heterodera glycines in greenhouse experiments. Journal of Nematology 46, 267-274.

450 Ito, D., Toyota, K. \& Sedrati, G.M. (2015). Suppression of the soybean cyst nematode, Heterodera glycines, using water extract of bean sprout residue. Nematology 17, 523-530. DOI: 10.1163/15685411-00002886

Ito, D., Toyota, K. \& Li, Z.G. (2017). Effect of Heterodera glycines and soil chemical and biological cultivation factors on the yield of green soybean grown in a glasshouse in Japan. Nematology 19, 237-244. DOI: 10.1163/15685411- 00003043

Kushida, A., Uehara, T. \& Momota, Y. (2002). Effect of red clover on hatching and population density of Heterodera glycines (Tylenchida: Heteroderidae). Japanese Journal of Nematology 32, 69-72.

Kushida, A., Suwa, N., Ueda, Y. \& Momota, Y. (2003). Effects of Crotalaria juncea and 460 C. spectabilis on hatching and population density of the soybean cyst nematode, Heterodera glycines (Tylenchida: Heteroderidae). Applied Entomology and Zoology 38, 393-399. 
Masamune, T., Anetai, M., Takasugi, M. \& Katsui, N. (1982). Isolation of a natural hatching stimulus, glycinoeclepin A, for the soybean cyst nematode. Nature 297, 495-496. DOI: $10.1038 / 297495 \mathrm{a} 0$

Okada, T. (1971). The hatching responses of the soybean cyst nematode, Heterodera glycines Ichinohe (Tylenchida : Heteroderidae). Applied Entomology and Zoology 6, 91-93.

Okada, T. (1977). Studies on the hatching factors of the soybean cyst nematode, Heterodera glycines Ichinohe. Japanese Journal of Nematology 6, 50-52.

Perry, R.N. (2002). Hatching. In: Lee, D.I. (Ed.). The biology of nematodes. London, UK, Taylor \& Francis, pp. 147-169.

Rich, J.R., Dunn, R.A. \& Noling, J.W. (2004). Nematicides: past and present use. In: Chen, Z.X., Chen, S.Y. \& Dickson, D.W. (Eds). Nematology: advances and perspectives. Vol. 2. Nematode management and utilization. Wallingford, UK, CAB International, pp. 1179-1200.

Sasser, J.N. \& Uzzell, G. (1991). Control of the soybean cyst nematode by crop-rotation in combination with a nematicide. Journal of Nematology 23, 344-347.

Shiina, Y., Tomata, Y., Miyashita, M. \& Tanino, K. (2010). Asymmetric total synthesis 480 of glycinoeclepin A: generation of a novel bridgehead anion species. The Chemical Society of Japan 39, 835-837. DOI: 10.1002/chin.201105207

Shirai, S. \& Toyota, K. (2019). Optimisation of a species-specific primer set to quantify the soybean cyst nematode, Heterodera glycines, in soil using real-time PCR. Nematology 21, 1037-1042. DOI: 10.1163/15685411-00003273

485 Smelser, R.B. \& Pedigo, L.P. (1992). Soybean seed yield and quality reduction by bean leaf beetle (Coleoptera: Chrysomelidae) pod injury. Journal of Economic Entomology 85, 2399-2403.

Tilmon, K.J., Hodgson, E.W., O’Neal, M.E. \& Ragsdale, D.W. (2011). Biology of the soybean aphid, Aphis glycines (Hemiptera: Aphididae) in the United States. Journal of Integrated Pest Management 2, A1-A7. DOI: 10.1603/IPM10016

Toyota, K., Goto, K. \& Ito, D. (2013). Effect of bean sprout residue on the hatching and density of the soybean cyst nematode Heterodera glycines in soil. Nematology 15, 923-927. DOI: 10.1163/15685411-00002730 
Wallace, H.R. (1954). Hydrostatic pressure-deficiency and the emergence of larvae from cysts of the beet eelworm. Nature 173, 502-503.

Wen, L., Lee-Marzano, S., Ortiz-Ribbing, L.M., Gruver, J., Hartman, G.L. \& Eastburn, D.M. (2017). Suppression of soilborne diseases of soybean with cover crop. Plant Disease 101, 1918-1928. DOI: 10.1094/PDIS-07-16-1067-RE

Wen, Y., Meyer, S.L.F., MacDonald, M.H., Zheng, L., Jing, C. \& Chitwood, D.J. (2019). $500 \quad$ Nematotoxicity of Paeonia spp. extracts and Camellia oleifera tea seed cake and extracts to Heterodera glycines and Meloidogyne incognita. Plant Disease 103, 2191-2198. DOI: 10.1094/PDIS-09-18-1663-RE

Wrather, J.A. \& Koenning, S.R. (2006). Estimates of disease effects on soybean yields in the United States 2003 to 2005. Journal of Nematology 38, 173-180. 
Table 1. Basic data of the soils used in this study.

\begin{tabular}{|c|c|c|c|c|c|c|}
\hline Soil & Location & Soil taxonomy & Sand $(\%)$ & Silt (\%) & Clay (\%) & Soil texture \\
\hline \multirow[t]{2}{*}{ C soil } & $35^{\circ} 18^{\prime} \mathrm{N}, 139^{\circ} 53^{\prime} \mathrm{E}$ & Haplic andosol & 38 & 59 & 3 & Silty loam \\
\hline & Chiba Pref. & & & & & \\
\hline \multirow[t]{2}{*}{ S soil } & $35^{\circ} 50^{\prime} \mathrm{N}, 139^{\circ} 51^{\prime} \mathrm{E}$ & Low humic & 42 & 28 & 30 & Light clay \\
\hline & Saitama & andosol & & & & \\
\hline \multirow[t]{2}{*}{ K soil } & $35^{\circ} 12^{\prime} \mathrm{N}, 139^{\circ} 39^{\prime} \mathrm{E}$ & Haplic andosol & 19 & 41 & 40 & Light clay \\
\hline & Kanagawa & & & & & \\
\hline \multirow[t]{2}{*}{$\mathrm{N}$ soil } & $34^{\circ} 29^{\prime} \mathrm{N}, 135^{\circ} 55^{\prime} \mathrm{E}$ & Grey lowland soil & 52 & 22 & 26 & Light clay \\
\hline & Nara Pref. & & & & & \\
\hline
\end{tabular}


510 Table 2. Summary of the field experiments.

\begin{tabular}{|c|c|c|c|c|c|c|c|c|}
\hline \multirow[t]{2}{*}{ Site } & \multirow{2}{*}{$\begin{array}{l}\text { No. of } \\
\text { field }\end{array}$} & \multirow[t]{2}{*}{ Treatment } & \multirow{2}{*}{$\begin{array}{l}\text { Sowing rate }(\mathrm{g} \\
\left.\mathrm{m}^{-2}\right) \text { of mung } \\
\text { bean }\end{array}$} & \multicolumn{2}{|c|}{ Irrigation } & \multirow{2}{*}{$\begin{array}{l}\text { Plastic } \\
\text { mulch }\end{array}$} & \multicolumn{2}{|c|}{ Soil sampling } \\
\hline & & & & $\begin{array}{c}\text { after } \\
\text { sowing }\end{array}$ & after incorporation & & Plot & $\begin{array}{l}\text { Plot size } \\
\qquad\left(\mathrm{m}^{-2}\right)\end{array}$ \\
\hline \multirow[t]{5}{*}{ Saitama } & 1 & Control & 0 & $x$ & $x$ & $x$ & 9 & 0.36 \\
\hline & & MB9 & 9 & $\circ^{1}$ & $x$ & $x$ & 9 & 0.36 \\
\hline & & MB9i & 9 & $\mathrm{O}^{1}$ & $\mathrm{O}^{2}$ & $x$ & 9 & 0.36 \\
\hline & & MB18i & 18 & $\circ^{1}$ & $\mathrm{O}^{2}$ & $x$ & 9 & 0.36 \\
\hline & & MB27i & 27 & $\mathrm{O}^{1}$ & $\mathrm{O}^{2}$ & $x$ & 9 & 0.36 \\
\hline Kanagawa & 4 & MB9 & 9 & $\triangle$ & $\triangle$ & $x$ & 3 & 1 \\
\hline \multirow[t]{2}{*}{ Nara } & 1 & Control & 0 & $\triangle$ & $\triangle$ & $\circ^{3}$ & 3 & 1 \\
\hline & & MB & 9 & $\triangle$ & $\triangle$ & $x$ & 3 & 1 \\
\hline
\end{tabular}

$\triangle$ : In open fields, irrigation was not conducted.

${ }^{1}$ After sowing, watering was done using irrigation tubes at a rate of $20 \mathrm{~L} \mathrm{~m}^{-2}$ every day for 3 days and at a rate of $10 \mathrm{~L} \mathrm{~m}^{-2} 5$ days after.

${ }^{2}$ After incorporation of mung bean by a tractor, irrigation at a rate of $40 \mathrm{~L} \mathrm{~m}^{-2}$ was done

515 in these treatments.

${ }^{3}$ After incorporation of mung bean by a tractor, mung bean plot was mulched with black polyethylene films

Control = no mung bean sowing; $\mathrm{MB} 9=$ sowing rate of mung bean was $9 \mathrm{~g} \mathrm{~m}^{-2}$ and irrigation was done only at sowing; $\mathrm{MB} 9 \mathrm{i}=$ sowing rate $\left(9 \mathrm{~g} \mathrm{~m}^{-2}\right)$ and irrigation were

520 done both at sowing and ploughing; MB18i = sowing rate $\left(18 \mathrm{~g} \mathrm{~m}^{-2}\right)$ and irrigation $(\times 2)$; and MB27i = sowing rate $\left(27 \mathrm{~g} \mathrm{~m}^{-2}\right)$ and irrigation $(\times 2)$. 


\section{Figure legends}

525

Fig. 1. Effect of constant (A) and alternating (B) temperature conditions on the number of Heterodera glycines second-stage juveniles in Chiba soil supplemented with mung bean solution. Values in $\mathrm{A}=$ mean $\pm \mathrm{SD}(\mathrm{n}=3)$; values in $\mathrm{B}=$ mean $\pm \mathrm{SD}$ $(n=4)$.

530

Fig. 2. Relationships between soil moisture contents and the number of Heterodera glycines second-stage juveniles (J2) in Saitama soil adjusted with different moisture levels, with incorporation of mung bean plants and incubation for 4 days. Control $=$ soils with no mung bean added; $\mathrm{MB}=$ soils with mung bean added. Each value is the 535 mean of two replicates.

Fig. 3. Effect of mung bean cultivation for 20 days and its ploughing on the density of Heterodera glycines in soil in a field at Saitama Prefecture 30 days after ploughing. Different letters indicate significant differences at $P<0.05$. control $=$ no mung bean sowing; MB9 = sowing rate of mung bean was $9 \mathrm{~g} \mathrm{~m}^{-2}$ and irrigation was done only at sowing; $\mathrm{MB} 9 \mathrm{i}=$ sowing rate $\left(9 \mathrm{~g} \mathrm{~m}^{-2}\right)$ and irrigation was done both at sowing and ploughing; MB18i = sowing rate $\left(18 \mathrm{~g} \mathrm{~m}^{-2}\right)$ and irrigation $(\times 2)$; and MB27i $=$ sowing rate $\left(27 \mathrm{~g} \mathrm{~m}^{-2}\right)$ and irrigation $(\times 2)$. Centre lines of boxes are median values and whiskers show 1.5 × IQR (Interquartile Range) $(n=9)$. $\times$ mean outliers.

$545 *$ The relative value of the $H$. glycines density after 30 days of ploughing to that at sowing $(100 \%)$. When the density increased from sowing to after ploughing, the value is shown as 100 (one replicate in control and MB27i).

Fig. 4. Temporal changes in soil moisture of MB9 and MB9i at depths of $10 \mathrm{~cm}$ to $15 \mathrm{~cm}$.

550 A line for $\mathrm{pF} 2.8$ is shown by a horizontal black line. MB9 $=$ sowing rate of mung bean $(9$ $\left.\mathrm{g} \mathrm{m}^{-2}\right)$ and irrigation were done only at sowing; $\mathrm{MB} 9 \mathrm{i}=$ sowing rate $\left(9 \mathrm{~g} \mathrm{~m}^{-2}\right)$ and irrigation were done both at sowing and ploughing. 
Fig. 5. Effect of mung bean cultivation and its ploughing on the density of Heterodera glycines in four different fields in Kanagawa prefecture. Each field had three replicate plots and values in each plot are shown. Each value is mean of two replicates. *The relative value of the SCN density after 14 days of ploughing to that at sowing (100\%). When the density increased from sowing to after ploughing, the value is shown as 100 (one replicate in Field Number 3).

Fig. 6. Effect of mung bean cultivation and its ploughing on the density of Heterodera glycines in a field in Nara Prefecture. Values are mean $\pm \mathrm{SD}(\mathrm{n}=3)$. Control = no mung bean; $\mathrm{MB}=$ mung bean was sown at a rate of $9 \mathrm{~g} \mathrm{~m}^{-2}$. $*$ The relative value of the SCN density after 22 days of ploughing to that 5 days before sowing (100\%). Different letters indicate significant difference at $P<0.05$.

Supplementary Fig. S1. Relationships between soil moisture content and pF values in (a); Saitama, (b); Kanagawa, (c); Nara-soils. Equations show their relationship (x $=\mathrm{pF}$ value, $\mathrm{y}=$ soil moisture content $)$ between two points in $\mathrm{pF}$ values .

570

Supplementary Fig. S2. Relationships between soil moisture content as measured by oven-drying and those measured with the moisture sensor 5TM.

Supplementary Fig. S3. Aboveground biomass of mung bean plants grown for 20 days after sowing. Different letters indicate significant differences at $P<0.05$. MB9 = sowing rate of mung bean was $9 \mathrm{~g} \mathrm{~m}^{-2}$ and irrigation was done only at sowing; MB9i = sowing rate, $9 \mathrm{~g} \mathrm{~m}^{-2}$ and irrigation was done both at sowing and ploughing; MB18i = sowing rate; $18 \mathrm{~g} \mathrm{~m}^{-2}$ and irrigation $(\times 2)$; and MB27i = sowing rate, $27 \mathrm{~g}$ $\mathrm{m}^{-2}$ and irrigation $(\times 2)$.

Supplementary Fig. S4. Temporal changes in soil temperature on MB9 and MB9i at depths of $10 \mathrm{~cm}$ to $15 \mathrm{~cm}$. MB9 = sowing rate of mung bean was $9 \mathrm{~g} \mathrm{~m}^{-2}$, and irrigation 
was done only at sowing; MB9i = sowing rate was $9 \mathrm{~g} \mathrm{~m}^{-2}$ and irrigation was done both at sowing and ploughing.

585

Supplementary Fig. S5. Temporal changes in soil moisture in control (no mung bean) and MB (mung bean sown at a rate of $9 \mathrm{~g} \mathrm{~m}^{-2}$ ) at a soil depth of $10 \mathrm{~cm}$ to $15 \mathrm{~cm}$.

Supplementary Fig. S6. Temporal changes in soil temperature in control (no mung 590 bean) and MB (mung bean sown at a rate of $9 \mathrm{~g} \mathrm{~m}^{-2}$ ) at a soil depth of $10 \mathrm{~cm}$ to $15 \mathrm{~cm}$. 